\title{
Yield of organically grown maize hybrids as affected by two green manure crops in Greece
}

\author{
Panagiotis Kanatas ${ }^{1 *}$, Ilias Travlos², Ioanna Kakabouki², Panagiota Papastylianou², \\ and Ioannis Gazoulis ${ }^{2}$
}

${ }^{1}$ Agricultural Cooperative of Mesolonghi-Nafpaktia, 30200 Mesolonghi, Greece. *Corresponding author (pakanatas@ gmail.com).
${ }^{2}$ Agricultural University of Athens, Department of Crop Science, Laboratory of Agronomy, 75 Iera Odos str., 11855, Athens, Greece

Received: 7 March 2020; Accepted: 26 March 2020; doi:10.4067/S0718-58392020000300334

\begin{abstract}
The effects of two manure crops on the yield of organically grown maize (Zea mays L.) hybrids were evaluated during the growing seasons 2017-2018 and 2018-2019. The experimental treatments included the use of red clover (Trifolium pratense L.) and white clover (T. repens L.) as green manure crops and an untreated control treatment. 'Factor', 'Dracma', and 'Brasco' were the maize hybrids studied. A split plot design was employed with three replicates. The results of ANOVA indicated that the number of kernels per row as well as number of kernels per plant and weight of 1000 kernels were affected by the different green manure treatments $(\mathrm{P}<0.001, \mathrm{P}<0.001$ and $\mathrm{P}<0.01$, respectively). Trifolium pratense residuals increased maize grain yield by up to $6 \%$ as compared to control treatment during the first year. Similar were the corresponding results recorded during the second experimental year. Trifolium repens green manure increased maize yield by approximately $5 \%$ during either the first or the second experimental year as compare to control treatment. Maize grain yield was influenced by the factor of hybrid either in the first or in the second year of the experiment $(\mathrm{P}<0.01$ and $\mathrm{P}<0.001$, respectively) and 'Factor' was by 5\%-6\% and 10\%-11\% more productive than 'Dracma' and 'Brasco'. In conclusion, the results of the present study proved that both red and white clovers were beneficial for the productivity of maize crop under the climatic conditions of Greece, while the selection of the appropriate hybrid can further improve grain yield.
\end{abstract}

Key words: Grain yield, green manure, maize hybrid, organic farming, Trifolium pratense, Trifolium repens.

\section{INTRODUCTION}

Efficient and economic utilization of natural resources is crucial in agriculture (Lichtenberg et al., 2010). In addition to conventional farming systems, increasingly more attention is paid to organic farming, which in general terms ensures an ecologically cleaner and healthier environment. However, the relatively low $\mathrm{N}$ availability in many organic crops is among the factors that limit yields (de Ponti et al., 2012; Röös et al., 2018). Therefore, several agronomic practices have been studied and used for soil enrichment with nutrients.

Cultivation of green manure crops is the main possibility for soil enrichment, especially with $\mathrm{N}$ and interest is increasing in recent decades (Travlos et al., 2014; Northup and Rao, 2016). The incorporation of $\mathrm{N}$-rich plant green material into the soil mobilizes $\mathrm{N}$ and intensifies microbiological processes, which result in improved plant $\mathrm{N}$ content and soil structure (Islam et al., 2018). The largest amount of organic matter is left in the soil with the residues of grasses, winter cereals, spring cereals, grain legumes and other crops (Skuodiene and Nekrosiene, 2007; Northup and Rao, 2016). Regarding legumes, several species (Trifolium spp., Medicago spp., Vicia spp., Pisum spp., Vigna spp., Lotus spp., etc.) have been used and evaluated under diverse conditions (Kumar et al., 2014; Travlos et al., 2014; Karyoti et al., 2018). In general, N accumulation by legumes reaches its peak in the period of blooming, which is the ideal time for cutting and ploughing, and starts decreasing in the period of seed formation (Travlos, 2010). 
Maize (Zea mays L.) is globally one of the most popular and productive grain crops. The rapid increase in maize productivity and the high grain yields of the recent decades are mostly due to more productive hybrids and inorganic fertilization (Guo et al., 2010; Travlos et al., 2011). One of the major challenges is to maintain such high yields without adverse environmental impacts and huge cost for the farmers and consequently many studies are lately focused on the application of more environmentally friendly or totally organic practices (Lamptey et al., 2017).

Green manure crops of $\mathrm{N}$-fixing legumes supply $\mathrm{N}$ to the cropping system and should therefore be considered as an important component of each crop rotation system (Martyniuk et al., 2019). The beneficial effects of Trifolium pratense L. as green manure on the number of grains per corncob and the final maize grain yield have been observed by Tejada et al. (2008). Incorporating clovers into the soil as green manure is a method well established in organic cropping systems (Breland, 1996). Growth parameters and productivity of cereals have been improved by the incorporation of T. repens $\mathrm{L}$. as green manure (Skuodiene and Nekrosiene, 2012; Koehler-Cole et al., 2017).

A vast array of legume species has shown potential as green manures. There are several hundred species of legumes, but only a fraction of these have been evaluated for their performance as green manures. The aim of the present study was to evaluate the effects of two legumes as green manure, red clover (T. pratense) and white clover (T. repens) on grain yield and quality characteristics of three organically grown maize hybrids.

\section{MATERIALS AND METHODS}

\section{Study site and experimental design}

A field experiment was conducted in 2017-2018 ( $\left(1^{\text {st }}\right.$ year) and repeated in 2018-2019 ( $2^{\text {nd }}$ year) in the experimental farm

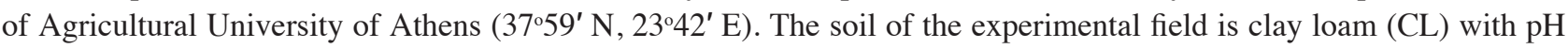
7.29 (Table 1). Typical climatic conditions for Greece were recorded during both experimental years (Table 2). A split plot design was employed in each growing season in a randomized complete block design with three replicates. Green manure crops were assigned to main plots and maize hybrids were assigned to subplots.

Table 1. Soil conditions in the experimental field of Agricultural University of Athens.

\begin{tabular}{lc}
\hline Parameter & Value \\
\hline $\mathrm{CaCO}_{3}, \%$ & 15.99 \\
$\mathrm{Organic} \mathrm{matter,} \mathrm{\%}_{\mathrm{NO}}^{-}, \mathrm{mg} \mathrm{kg}^{-1}$ & 2.37 \\
$\mathrm{P}(\mathrm{Olsen}), \mathrm{mg} \mathrm{kg}^{-1}$ & 104.30 \\
$\mathrm{Na}^{+}, \mathrm{mg} \mathrm{kg}^{-1}$ & 9.95 \\
$\mathrm{pH}$ & 110.00 \\
Soil texture & 7.29 \\
\hline
\end{tabular}

Table 2. Mean maximum, minimum temperature and rainfall values recorded for each month during the first (2017-2018) and the second (2018-2019) experimental year.

\begin{tabular}{|c|c|c|c|c|c|c|}
\hline \multirow[b]{2}{*}{ Month } & \multicolumn{3}{|c|}{ 2017-2018 } & \multicolumn{3}{|c|}{ 2018-2019 } \\
\hline & $\operatorname{Max} T$ & Min T & Rainfall & $\operatorname{Max} T$ & Min T & Rainfall \\
\hline & \multicolumn{2}{|c|}{$\longrightarrow{ }^{\circ} \mathrm{C}$} & $\mathrm{mm}$ & \multicolumn{2}{|c|}{${ }^{\circ} \mathrm{C}$} & $\mathrm{mm}$ \\
\hline October & 27.4 & 12.7 & 6.6 & 26.8 & 9.4 & 0.6 \\
\hline November & 23.3 & 6.4 & 130.2 & 28.1 & 7.6 & 51.6 \\
\hline December & 21.7 & 4.8 & 27.0 & 19.3 & 3.7 & 73.7 \\
\hline January & 17.7 & 3.5 & 51.4 & 16.8 & -0.1 & 125.0 \\
\hline February & 18.9 & 6.3 & 80.0 & 19.1 & 3.3 & 59.2 \\
\hline March & 22.6 & 6.8 & 11.2 & 24.1 & 5.3 & 26.8 \\
\hline April & 29.8 & 11.0 & 1.8 & 25.8 & 8.0 & 115.0 \\
\hline May & 29.6 & 16.0 & 67.8 & 30.2 & 11.2 & 2.2 \\
\hline June & 33.9 & 19.3 & 57.2 & 35.2 & 17.9 & 2.6 \\
\hline July & 33.4 & 24.7 & 65.2 & 32.6 & 23.8 & 1.0 \\
\hline August & 32.8 & 24.5 & 6.4 & 33.6 & 25.6 & 0.0 \\
\hline September & 29.2 & 21.0 & 43.8 & 32.7 & 21.0 & 4.8 \\
\hline
\end{tabular}




\section{Experimental treatments and maize hybrids}

Two legume species were tested for green manuring. In particular, red clover (Trifolium pratense L.) and white clover ( $T$. repens L.) at seed rates of $15 \mathrm{~kg} \mathrm{ha}^{-1}$ were sown, while an untreated control (without any crop as green manure) was also included. Legumes were sown on 19 September 2017 and 24 September 2018. Legumes were chopped and ploughed in on 17 March 2018 and 9 March 2019 and the soil was prepared for maize sowing. Three maize hybrids, namely 'Factor' 127-d relative maturity (RM), 'Dracma' 126-d RM, and 'Brasco' 128-d RM were planted on 11 April 2018 and 4 April 2019. The three hybrids have similar biological cycle (FAO 700), plant height (moderate/high) and productivity (stable and high). They were planted in $75 \mathrm{~cm}$ rows at an approximate density of about 75000 seeds ha ${ }^{-1}$. The size of each subplot was $2.25 \mathrm{~m} \times 3 \mathrm{~m}$. Maize rows were numbered 1 to 4 from left to right. Rows 1 and 4 were border rows, while yield data were collected from rows 3 and no inorganic fertilizers or plant protection products were used.

\section{Measurements}

The biomass of the above-ground part of the two legumes was measured in each plot just before ploughing by cutting three $1 \times 4 \mathrm{~m}$ strips. Biomass was dried at $70{ }^{\circ} \mathrm{C}$ and then analyzed for $\mathrm{N}$ by Kjeldahl method and for $\mathrm{P}$ and $\mathrm{K}$ by spectrophotometry. At maize grain maturity (middle of September for both growing seasons), ears of 10 plants of the center rows of each sub plot were hand-harvested and dried at $70{ }^{\circ} \mathrm{C}$ until constant weight was achieved. Grain yield, rows per ear, kernels per row, kernels per plant and 1000 kernel weight were determined while $\mathrm{N}$ content was also measured in the grains and protein content determined.

\section{Statistical analysis}

ANOVA was conducted for all data and differences between means were compared at the $5 \%$ level of significance using the Fisher's protected LSD test. Regarding the comparisons between biomass, N, P and K contents of the two green manure crops, a t-test statistics was carried out. All statistical analyses were conducted using the Statsoft software package (Statsoft, Tulsa, Oklahoma, USA).

\section{RESULTS AND DISCUSSION}

\section{Biomass and aboveground $\mathrm{N}, \mathrm{P}$ and $\mathrm{K}$ content in legumes}

Measurements of the biomass of the two legumes revealed that $T$. pratense produced $21 \%$ more biomass than $T$. repens whereas N, P and K contents were increased by $20 \%, 31 \%$ and $20 \%$, respectively, in the residuals of $T$. pratense plants as compared to the corresponding values recorded for T. repens residuals (Table 3 ). The results described above were tested by using t-test statistics and the null hypothesis was rejected $(\mathrm{P}<0.05)$ (Table 4). This result could be attributed to the lower growth rate of white clover and is in common direction with the findings of previous studies conducted by Skuodiene and Nekrosiene (2007) and Koehler-Cole et al. (2017).

Integrated effects of green manure, hybrid selection and experimental year on yield components of maize and maize grain yield

The results of ANOVA showed that the number of kernels per row as well as the number of kernels per plant and weight of 1000 kernels were the components of maize grain yield most affected by the different green manure treatments $(\mathrm{P}<0.001, \mathrm{P}<0.001$ and $\mathrm{P}<0.01$, respectively). Regarding hybrid selection, its influence on these traits

Table 3. Biomass and content of $N, P$ and $K$ in the aboveground part of legumes ploughed in the soil as green manure. Data were averaged over the two growing seasons.

\begin{tabular}{lcc}
\hline Parameter & Trifolium pratense & T. repens \\
\hline Biomass, $\mathrm{Mg} \mathrm{ha}^{-1}$ & $4.14 \mathrm{a}$ & $3.26 \mathrm{~b}$ \\
$\mathrm{~N}, \mathrm{~kg} \mathrm{ha}^{-1}$ & $122.00 \mathrm{a}$ & $97.00 \mathrm{~b}$ \\
$\mathrm{P}, \mathrm{kg} \mathrm{ha}^{-1}$ & $16.00 \mathrm{a}$ & $11.00 \mathrm{~b}$ \\
$\mathrm{~K}, \mathrm{~kg} \mathrm{ha}^{-1}$ & $77.00 \mathrm{a}$ & $61.00 \mathrm{~b}$ \\
\hline
\end{tabular}

Means followed by different letters within the same row indicate significant differences according to t-test $(\mathrm{a}=0.05)$. The results of t-test are shown in the following Table 4. 
Table 4. Comparison of the means of Trifolium pratense and T. repens regarding biomass, $\mathrm{N}$, $\mathrm{P}$ and $\mathrm{K}$ contents using Student's t-test at $\mathrm{a}=\mathbf{0 . 0 5}$. Null hypothesis: mean of $T$. pratense $=$ mean of $T$. repens. Alternative hypothesis: mean of $T$. pratense $>$ mean of $T$. repens.

\begin{tabular}{lccc}
\hline Parameter & $\mathrm{t}$ & $\mathrm{P}$-Value & Null hypothesis \\
\hline Biomass, $\mathrm{Mg} \mathrm{ha}^{-1}$ & 20.5368 & $*$ & Rejected \\
$\mathrm{N}, \mathrm{kg} \mathrm{ha}^{-1}$ & 8.51943 & $*$ & Rejected \\
$\mathrm{P}, \mathrm{kg} \mathrm{ha}^{-1}$ & 5.22233 & $*$ & Rejected \\
$\mathrm{K}, \mathrm{kg} \mathrm{ha}^{-1}$ & 7.45105 & $*$ & Rejected \\
\hline
\end{tabular}

*Significant at the 0.05 probability level.

was not clear. Regarding final yield performance of maize, it was affected by the different green manure treatments as well as by hybrid selection during both experimental years $(\mathrm{P}<0.01$ and $\mathrm{P}<0.001$, respectively). Maize grain yield was not affected by the year factor. Furthermore, neither the interaction between the different green manure treatments and hybrids nor the interaction between the factors of hybrid selection and year did put impact on the components of yield and maize grain yield during both experimental years. The same observation was made regarding the integrated effects of green manure, hybrid selection and year on components of yield and yield performance of maize (Table 5).

\section{Effects of green manure on yield components of maize for each experimental year}

ANOVA was also carried out to analyze data of each experimental year. Fischer's protected LSD $(a=0.05)$ multiple range test was used in order to detect significant differences in maize yield and components of yield between the means of the three experimental treatments as well as between the means of the three maize hybrids. In particular, it was revealed that in plots where T.repens was incorporated as green manure the number of kernels per row was $13 \%$ and $11 \%$ higher than the corresponding value recorded in untreated plots during the first experimental year and the second experimental year, respectively. Trifolium pratense residuals increased the number of kernels per row by $16 \%$ and $14 \%$ as compared to control treatment as it was shown from the results of the first and the second year, respectively (Table 6). Similar were the observations regarding the number of kernels per plant. This specific component of yield was increased by $12 \%-14 \%$ and 15\%-18\% due to the use of T.pratense and T. repens green manure, respectively, as compared to untreated control (Table 7). Incorporating T. repens as green manure instead of leaving the field untreated can result in $11 \%-15 \%$ higher value of weight of 1000 kernels. Similar can be the effects of $T$. pratense residuals on the value of this trait, especially as recorded during the second year of the study (Table 8). The results of the current study showed that green manure can affect components of maize yield and are in line with the results of Dabin et al. (2015), who observed that the number of spikes per hectare under the green manure legume treatment was significantly greater than that recorded under the control treatment. In contrast to these findings, the results of an earlier study indicated that components of yield were unaffected by green manure treatments (Astier et al., 2006). However, in the study of Turgut et al. (2005) average ear yields of corn were greater in plots receiving green manuring as compared to untreated plots and also other components of yield were enhanced by the adoption of green manuring.

Table 5. Significances from ANOVA for maize grain yield and components of yield.

\begin{tabular}{|c|c|c|c|c|c|c|}
\hline Source & Df & $\begin{array}{l}\text { Grain } \\
\text { yield }\end{array}$ & $\begin{array}{l}\text { Rows } \\
\text { ear }^{-1}\end{array}$ & $\begin{array}{c}\text { Kernels } \\
\text { row }^{-1}\end{array}$ & $\begin{array}{l}\text { Kernels } \\
\text { plant }^{-1}\end{array}$ & $\begin{array}{c}\text { Weight of } 1000 \\
\text { kernels }\end{array}$ \\
\hline & & $\mathrm{Mg} \mathrm{ha}^{-1}$ & & & & $\mathrm{~g}$ \\
\hline Green manure (GM) & 2 & $* *$ & ns & $* * *$ & $* * *$ & $* *$ \\
\hline Hybrid (H) & 2 & $* * *$ & ns & ns & ns & ns \\
\hline Year $(Y)$ & 1 & ns & ns & ns & ns & ns \\
\hline Green manure $\times$ Hybrid & 4 & ns & ns & ns & ns & ns \\
\hline Green manure $\times$ Year & 2 & ns & ns & ns & ns & ns \\
\hline Hybrid $\times$ Year & 2 & ns & ns & ns & ns & ns \\
\hline $\mathrm{GM} \times \mathrm{H} \times \mathrm{Y}$ & 4 & ns & ns & ns & ns & ns \\
\hline Error & 34 & & & & & \\
\hline
\end{tabular}

$* *$,***Significant at the 0.01 and 0.001 probability levels, respectively; ns: nonsignificant; Df: degrees of freedom. 
Table 6. Effects of green manure treatments and maize hybrid selection on the number of kernels per row during the first (2017-2018) and the second (2018-2019) experimental year.

\begin{tabular}{lcc}
\hline & $2017-2018$ & $2018-2019$ \\
\hline & Kernels row $^{-1}$ & Kernels row $^{-1}$ \\
Green manure (GM) & & \\
$\quad$ Untreated & $25.8222 \mathrm{~b}$ & $26.2889 \mathrm{~b}$ \\
Trifolium pratense & $30.7111 \mathrm{a}$ & $30.6000 \mathrm{a}$ \\
T. repens & $29.6667 \mathrm{a}$ & $29.6333 \mathrm{a}$ \\
Hybrid (H) & & \\
Factor & $28.2778 \mathrm{a}$ & $29.0111 \mathrm{a}$ \\
Dracma & $28.1111 \mathrm{a}$ & $28.0000 \mathrm{a}$ \\
Brasco & $29.8111 \mathrm{a}$ & $29.5111 \mathrm{a}$ \\
P-Values & & $*$ \\
Treatment & $* *$ & $\mathrm{~ns}$ \\
Hybrid & $\mathrm{ns}$ & $\mathrm{ns}$ \\
T $\times \mathrm{H}$ & $\mathrm{ns}$ &
\end{tabular}

Means followed by different letters within the same column indicate significant differences according to Fisher's Protected LSD test multiple range test $(\mathrm{a}=0.05)$.

$*, * *$ Significant at the 0.05 and 0.01 probability levels, respectively; ns: nonsignificant.

Table 7. Effects of green manure treatments and maize hybrid selection on the number of kernels per plant during the first (2017-2018) and the second (2018-2019) experimental year.

\begin{tabular}{lcc}
\hline & $2017-2018$ & $2018-2019$ \\
\hline & Kernels plant $^{-1}$ & Kernels plant $^{-1}$ \\
Green manure (GM) & & \\
Untreated & $341.444 \mathrm{~b}$ & $328.000 \mathrm{~b}$ \\
Trifolium pratense & $387.444 \mathrm{a}$ & $381.556 \mathrm{a}$ \\
T. repens & $402.000 \mathrm{a}$ & $401.222 \mathrm{a}$ \\
Hybrid (H) & & \\
Factor & $391.333 \mathrm{a}$ & $364.667 \mathrm{a}$ \\
Dracma & $363.444 \mathrm{a}$ & $362.222 \mathrm{a}$ \\
Brasco & $376.111 \mathrm{a}$ & $383.889 \mathrm{a}$ \\
P-Values & & $* * *$ \\
Treatment & $* * *$ & $\mathrm{~ns}$ \\
Hybrid & $\mathrm{ns}$ & $\mathrm{ns}$ \\
T $\times \mathrm{H}$ & $\mathrm{ns}$ & \\
\hline
\end{tabular}

Means followed by different letters within the same column indicate significant differences according to Fisher's Protected LSD test multiple range test $(\mathrm{a}=0.05)$.

***Significant at the 0.001 probability levels; ns: nonsignificant.

\section{Effects of green manure on maize grain yield for each experimental year}

Major components of yield were affected by the adoption of different green manures and consequently these differences did exert a great influence in the final grain yield of maize. Maize grain yield differences between the several treatments could largely be attributed to the number of kernels produced and their weight, since it is well documented that maize grain yield is mainly determined by kernel number and weight (Travlos et al., 2011). Trifolium repens green manure increased maize yield by approximately 5\% during either the first or the second experimental year as compare to control treatment. In plots where $T$. pratense residuals were incorporated as green manure, maize yield was increased by up to $6 \%$ during the first year of the experiment and almost these results were validated during the second experimental year (Table 9). The positive effects of green manure legume crops on maize grain yield is in agreement with the findings of Sileshi et al. (2008). The adoption of green manure as fertilization tactics can increase maize grain yield by enhancing the content organic matter into the soil profiles as well as crop growth parameters (Salahin et al., 2013). It has also to be noted that maize yield after the use of red clover was slightly higher than white clover, probably due to the higher biomass, confirming previous studies suggesting that red clover is among the best species for use as green manure (Koehler-Cole et al., 2017). In another study, $T$. pratense green manure improved the value of the number of grains per ear and consequently maize grain yield as compared to untreated control (Tejada et al., 2008). The effects of green manure legumes on the yields of the subsequent crop, have also been noticed in wheat and rye crops as well as in oriental sun-cured tobacco (Skuodiene and Nekrosiene, 
2007; Travlos et al., 2014). These findings can be explained by the fact that crop yield increases due to the fact that green manure as adds $\mathrm{N}$ and has additional beneficial effects on soil properties (Skoufogianni et al., 2013). It is well established that the incorporation of quality organic inputs provides rapid and efficient accumulation of nutrient uptakes for the crop by releasing nutrients in synchrony with plant demands (Martyniuk et al., 2019). The results of Dhima et al. (2009) indicated also that green manure of aromatic species can increase the final grain yield by reducing weed infestation in maize crops. This finding indicates that except for the parameter of crop yield, the possible role of green manure as weed management practice sets a new unexplored area which needs to be investigated in organic farming.

\section{Effects of hybrid selection on yield components of maize}

Regarding hybrid selection, it did not affect the components of maize yield during both experimental years $(\mathrm{P}>0.05)$. However, there is evidence that the number of grains per ear is most dominated by genetic factors in comparison to management practices (Shah and Arif, 2000). In addition, cultivar selection affected the number of grains per ear in the study of Ali et al. (2011). The weight of 1000 grains is an important factor directly contributing to final grain yield of crop. Although the results of this study did not indicate clearly the effect of hybrid selection on its value $(\mathrm{P}>0.05)$, a prominent effect of different hybrids on the weight of 1000 grains has been reported in previous studies (Tahir et al., 2008; Inamullah et al., 2011).

Table 8. Effects of green manure treatments and maize hybrid selection on the weight of 1000 kernels (g) during the first (2017-2018) and the second (2018-2019) experimental year.

\begin{tabular}{lcc}
\hline & $2017-2018$ & $2018-2019$ \\
\hline & $\mathrm{g}$ & $\mathrm{g}$ \\
Green manure (GM) & & $208.889 \mathrm{~b}$ \\
$\quad$ Untreated & $205.111 \mathrm{~b}$ & $230.556 \mathrm{a}$ \\
Trifolium pratense & $219.000 \mathrm{ab}$ & $229.000 \mathrm{a}$ \\
T. repens & $230.556 \mathrm{a}$ & \\
Hybrid (H) & & $227.111 \mathrm{a}$ \\
Factor & $218.778 \mathrm{a}$ & $218.889 \mathrm{a}$ \\
Dracma & $214.333 \mathrm{a}$ & $222.444 \mathrm{a}$ \\
Brasco & $221.556 \mathrm{a}$ & $* * *$ \\
P-Values & & $\mathrm{ns}$ \\
Treatment & $\mathrm{ns}$ & $\mathrm{ns}$ \\
Hybrid & $\mathrm{ns}$ & $\mathrm{ns}$ \\
T $\times$ H & $\mathrm{ns}$
\end{tabular}

Means followed by different letters within the same column indicate significant differences according to Fisher's Protected LSD test multiple range test $(\mathrm{a}=0.05)$.

***Significant at the 0.001 probability levels; ns: nonsignificant.

Table 9. Effects of green manure treatments and maize hybrid selection on grain yield during the first (2017-2018) and the second (2018-2019) experimental year.

\begin{tabular}{lcc}
\hline & $2017-2018$ & $2018-2019$ \\
\hline & $\mathrm{Mg} \mathrm{ha}^{-1}$ & $\mathrm{Mg} \mathrm{ha}^{-1}$ \\
Green manure (GM) & & \\
$\quad$ Untreated & $10.8222 \mathrm{~b}$ & $10.8222 \mathrm{a}$ \\
Trifolium pratense & $11.5444 \mathrm{a}$ & $11.4000 \mathrm{a}$ \\
T. repens & $11.4333 \mathrm{a}$ & $11.3333 \mathrm{a}$ \\
Hybrid (H) & & \\
Factor & $11.8778 \mathrm{a}$ & $11.9000 \mathrm{a}$ \\
Dracma & $11.2778 \mathrm{~b}$ & $11.1444 \mathrm{~b}$ \\
Brasco & $10.6444 \mathrm{c}$ & $10.5111 \mathrm{c}$ \\
P-Values & & $* * *$ \\
Treatment & $* *$ & $\mathrm{~ns}$ \\
Hybrid & $*$ & $\mathrm{~ns}$ \\
T $\times \mathrm{H}$ & $\mathrm{ns}$ & \\
\hline
\end{tabular}

Means followed by different letters within the same column indicate significant differences according to Fisher's Protected LSD test multiple range test $(\mathrm{a}=0.05)$.

$*, * *, * * *$ Significant at the $0.05,0.01$ and 0.001 probability levels, respectively; ns: nonsignificant. 


\section{Effects of hybrid selection on maize grain yield for each experimental year}

Maize grain yield was influenced by hybrid factor either in the first or in the second year of the experiment $(\mathrm{P}<0.01$ and $\mathrm{P}<0.001$, respectively). In particular, 'Factor' was 5\%-6\% more productive than 'Dracma'. In the subplots of hybrid 'Factor' grain yield was $10 \%$ and $11 \%$ higher than the corresponding value recorded in the subplots of 'Brasco', during the first and second experimental year, respectively. Except for the superiority of 'Factor', the recorded grain yield of 'Dracma' was by approximately $5 \%$ greater as compared to the recorded yield of 'Brasco' for both experimental years. Moreover, in the slightly less favorable hydrothermal conditions of 2018-2019 in comparison with 2017-2018, maize grain yield on average in hybrids was in most cases lower by 0.07 to $0.23 \mathrm{t} \mathrm{ha}^{-1}$. This observation is in line with the findings of previous studies (Kadyrov and Kharitonov, 2019). The impact of genotype on maize yield performance as well as on yield components such as grains per ear and weight of 1000 grains have been noted in the study of Ali et al. (2011). The findings of Travlos et al. (2011) indicated that selecting hybrids with a relatively high first growth rate can be an effective weed management strategy and thus, results in increased maize grain yield. The importance of hybrid and cultivar selection has been noted to influence maize yield in various circumstances and different cropping systems (Wortman et al., 2013). Another example is that drought tolerant hybrids can be up to 7\% more productive as compared to non-drought tolerant hybrids in different evapotranspiration environments as it has been observed by Adee et al. (2016).

\section{Integrated effects of green manure, hybrid selection and experimental year on protein content of maize grains}

Crude protein is a primary quality component of cereal grains. Protein concentration is influenced by both environmental and genotypic factors that are difficult to separate (Surma et al., 2012). In our case, there were nonsignificant effect of year or maize hybrid on grain protein content or a significant correlation of protein content with grain yield. However, green manure did exert an influence on grain protein content $(\mathrm{P}<0.05)$, with the protein content of maize after the use of red and white clover ranged between $6.89 \%$ and $7.63 \%$ and being in average $8 \%-19 \%$ higher than the content of grains produced without any previous incorporation of green manure crops (data not shown). Our results are in agreement with the findings of previous studies, indicating that protein content of grain can be significantly affected by the incorporation of different green manure legume crop residuals (Skuodiene and Nekrosiene, 2007).

\section{CONCLUSIONS}

Red clover produced significantly more biomass than white clover. The adoption of both red and white clover as green manure crops improved maize grain yield as compared to the corresponding value recorded in untreated plots. Furthermore, the current study also indicated that selecting the appropriate hybrid can lead to increased grain yield. Green manure did also affect grain protein content. Conclusively, the results of the present study proved that both red and white clovers were beneficial for the productivity of maize crop under the climatic conditions of Greece.

\section{REFERENCES}

Adee, E., Roozeboom, K., Balboa, G.R., Schlegel, A., and Ciampitti, I.A. 2016. Drought-tolerant corn hybrids yield more in drought-stressed environments with no penalty in non-stressed environments. Frontiers in Plant Science 7:1534. doi:10.3389/fpls.2016.01534.

Ali, K., Munsif, F., Zubair, M., Hussain, Z., Shahid, M., Din, I.U., et al. 2011. Management of organic and inorganic nitrogen for different maize varieties. Sarhad Journal of Agriculture 27:525-529.

Astier, M., Maass, J.M., Etchevers-Barra, J.D., Peña, J.J., and González, F. de L. 2006. Short-term green manure and tillage management effects on maize yield and soil quality in an Andisol. Soil and Tillage Research 88:153-159.

Breland, T.A. 1996. Green manuring with clover and ryegrass catch crops undersown in small grains: effects on soil mineral nitrogen in field and laboratory experiments. Acta Agriculturae Scandinavica 46:178-185.

Dabin,Z., Pengwei, Y., Na, Z., Zheng, W., Changwei, Y., Qunhu, C., et al. 2015. Responses of winter wheat production to green manure and nitrogen fertilizer on the Loess Plateau. Agronomy Journal 107:361.

de Ponti, T., Rijk, B., and van Ittersum, M.K. 2012. The crop yield gap between organic and conventional agriculture. Agricultural Systems 108:1-9.

Dhima, K.V., Vasilakoglou, I.B., Gatsis, T.D., Panou-Philotheou, E., and Eleftherohorinos, I.G. 2009. Effects of aromatic plants incorporated as green manure on weed and maize development. Field Crops Research 110:235-241. 
Guo, S.L., Wu, J.S., Dang, T.H., Liu, W.Z., Li, Y., Wei, W.X., et al. 2010. Impacts of fertilizer practices on environmental risk of nitrate in semiarid farmlands in the Loess Plateau of China. Plant and Soil 330:1-13.

Inamullah, N.R., Shah, N.H., Arif, M., Siddiq, M., and Mian, I.A. 2011. Correlations among grain yield and yield attributes in maize hybrids at various nitrogen levels. Sarhad Journal of Agriculture 27:531-538.

Islam, M.M.,Urmi, T.A., Rana, M.S., Alam,M.S., and Haque, M.M.2018. Green manuring effects on crop morpho-physiological characters, rice yield and soil properties. Physiology \& Molecular Biology of Plants 25:303-312.

Kadyrov, S., and Kharitonov, M. 2019. Productivity of corn hybrids in relation to the seeding rate. Agronomy Research 17:123-132.

Karyoti, A., Bartzialis, D., Sakellariou-Makrantonaki, M., and Danalatos, N. 2018. Effects of irrigation and green manure on corn (Zea mays L.) biomass and grain yield. Journal of Soil Science and Plant Nutrition 18:820-832.

Koehler-Cole, K., Brandle, J.R., Francis, C.A., Blankeship, E.E., and Baenziger, S. 2017. Clover green manure productivity and weed suppression in an organic grain rotation. Renewable Agriculture and Food Systems 32:474-483.

Kumar, R., Mahajan, G., Srivastava, S., and Sinha, A. 2014. Green manuring: a boom for sustainable agriculture and pest management-a review. Agricultural Reviews 35:196-206.

Lamptey, S., Yeboah, S., Li, L., and Zhang, R. 2017. Dry matter accumulation and nitrogen concentration in forage and grain maize in dryland areas under different soil amendments. Agronomy Research 15:1646-1658.

Lichtenberg, E., Shortle, J., Wilen, J., and Zilberman, D. 2010. Natural resources economics and conservation: contributions of agricultural economics and agricultural economists. American Journal of Agricultural Economics 92:469-486.

Martyniuk, S., Pikula, D., and Koziel, M. 2019. Soil properties and productivity in two long-term crop rotations differing with respect to organic matter management on an Albic Luvisol. Scientific Reports 9:1878.

Northup, B.K., and Rao, S.C. 2016. Effects of legume green manures on forage produced in continuous wheat systems. Agronomy Journal 108:101-108.

Röös, E., Mie, A., Wivstad, M., Salomon, E., Johannson, B., Gunnarsson, S., et al. 2018. Risks and opportunities of increasing yields in organic farming. A review. Agronomy for Sustainable Development 38:14.

Salahin, N., Alam, M.K., Islam, M.M., Naher, L., and Majid, N.M. 2013. Effects of green manure crops and tillage practice on maize and rice yields and soil properties. Australian Journal of Crop Science 7:1901.

Shah, K.P., and Arif, M. 2000. Management of organic farming: Effectiveness of farmyard manure (FYM) and nitrogen for maize productivity. Sarhad Journal of Agriculture 16:461-465.

Sileshi, G., Akinnifesi, F.K., Ajayi, O.C., and Place, F. 2008. Meta-analysis of maize yield response to woody and herbaceous legumes in sub-Saharan Africa. Plant and Soil 307:1-19.

Skoufogianni, E., Danalatos, N.G., Dimoyiannis, D., and Efthimiadis, P. 2013. Effects of pea cultivation as cover crop on nitrogen-use efficiency and nitrogen uptake by subsequent maize and sunflower crops in a sandy soil in central Greece. Communications in Soil Science and Plant Analysis 44:1-4.

Skuodiene, R., and Nekrosiene, R. 2007. Impact of perennial legumes and timothy as green manure on productivity of Secale cereale L. and $\times$ Triticosecale Wittm and an occurrence of cereal diseases. Agronomy Research 5:59-71.

Skuodiene, R., and Nekrosiene, R. 2012. The effect of perennials as green manure on cereal productivity and disease incidence. Spanish Journal of Agricultural Research 10:44-54.

Surma, M., Adamski, T., Banaszak, Z., Kaczmarek,Z., Kuczynska, H., Majcher, M., et al. 2012. Effect of genotype, environment and their interaction on quality parameters of wheat breeding lines of diverse grain hardness. Plant Production Science $15: 192-203$

Tahir, M., Tanveer, A., Ali, A., Abbas, M., and Wasaya, A. 2008. Comparative yield performance of different maize (Zea mays L.) hybrids under local conditions of Faisalabad-Pakistan. Pakistan Journal of Life and Social Sciences 6:118-120.

Tejada, M., Gonzalez, J.L., García-Martínez, A.M., and Parrado, J. 2008. Effects of different green manures on soil biological properties and maize yield. Bioresource Technology 99:1758-1767.

Travlos, I.S. 2010. Legumes as cover crops or components of intercropping systems and their effects on weed populations and crop productivity. p. 151-164. In Greco, A.J. (ed.) Advances in food science and technology. Nova Science Publishers, Hauppauge, New York, USA.

Travlos, I.S., Economou, G., and Kanatas, P.J. 2011. Corn and barnyardgrass competition as influenced by relative time of emergence and corn hybrid. Agronomy Journal 103:1-6.

Travlos, I.S., Kanatas, P.J., Tsioros, S., Papastylianou, P., Papatheohari, Y., and Bilalis, D. 2014. Effects of legume incorporation and pendimethalin application on oriental sun-cured tobacco. Agronomy Journal 106:1225-1230.

Turgut, I., Bilgili, U., Duman, A., and Acikgoz, E. 2005. Effect of green manuring on the yield of sweet corn. Agronomy for Sustainable Development 25:433-438.

Wortman, S.E., Francis, C.A., Galusha, T.D., Hoagland, C., Van Wart, J., Baenziger, P.S., et al. 2013. Evaluating cultivars for organic farming: Maize, soybean, and wheat genotype by system interactions in Eastern Nebraska. Agroecology and Sustainable Food Systems 37:915-932. 